\title{
An unexpected record of Teratohyla midas (Lynch and Duellman, 1973) for Brazil reveals the presence of glassfrogs in the Brazilian northern lowlands (Anura: Centrolenidae)
}

\author{
Rafael Pontes* and Camila Mattedi \\ Universidade Federal do Rio de Janeiro, Museu Nacional. Departamento de Vertebrados, Setor de Herpetologia. Quinta da Boa Vista s/ nº, São \\ Cristóvão. CEP 20940-040. Rio de Janeiro, RJ, Brazil. \\ * Corresponding author. E-mail: rafaelcunhapontes@hotmail.com
}

\begin{abstract}
We reported a new record of Teratohyla midas for Northeast Brazil and extending its distribution in 1,200km east from the nearest reported area. Additionally we constructed a distribution map based on literature records. Previously to this study, this species was known to occur in Ecuador, Peru, Colombia, Brazil (states of Amazonas and Rondônia), and an isolated population in French Guyana. Also, this record represents the first for Centrolenidae in transitional forests between Cerrado and Amazon biomes.
\end{abstract}

Glassfrogs (family Centrolenidae Taylor, 1951) are conspicuous inhabitants of Neotropical forests where they usually occur along streams and creeks (CisnerosHeredia and McDiarmid 2007). Presently, 152 species are recognized in this monophyletic group from Central America, tropical Andean region, and in the Guyana Shield (Castroviejo-Fisher et al. 2011; Guayasamin et al. 2009; Frost 2013); however, an isolated group inhabits the Atlantic Forest biome from Southeastern Brazil to adjacent Argentina (Heyer 1985).

Teratohyla midas (Lynch and Duellman, 1973), which was described from Santa Cecília, province of Napo, Ecuador, have most records reported for Amazonian Basin of Northeastern Ecuador, Peru and Colombia (Lynch and Duellman 1973; Cisneros-Heredia and McDiarmid 2005; França and Venâncio 2010; Malambo et al. 2013; Melo-Sampaio and Oliveira 2013). Furthermore, Kok and Castroviejo-Fisher (2008) documented this species for Crique Grand Leblond, French Guyana, the northernmost record. Nevertheless, authors flagged its occurrence as presumable for Northwestern Brazil and Southeastern Colombia (Rodríguez et al. 2012; Frost 2013). According to the original description (Lynch and Duellman 1973), T. midas is characterized by the following traits: 1) 1-3 prevomerine teeth; (2) green bones in life; (3) parietal peritoneum is white and visceral peritoneum opaque; (4) in preservative dorsal coloration is lavender with white flecks; (5) extensive webbing between third and fourth fingers; (6) snout truncate in dorsal view and profile; (7) skin texture shagreen; (8) absence of dermal folds in forearms and hind limbs; and (9) lower two thirds of tympanum is visible and posteriorly oriented.

While examining a collection of centrolenid specimens from the Museu Nacional, Universidade Federal do Rio de Janeiro (MNRJ), we found a specimen (Figure 1) of Teratohyla midas (MNRJ 23856) labeled as Vitreorana oyampiensis (Lescure 1975). The specimen is an adult male, SVL $19.5 \mathrm{~mm}$, collected at Municipality of São Pedro da Água Branca $\left(05^{\circ} 05^{\prime} 06^{\prime \prime S}, 48^{\circ} 25^{\prime} 45^{\prime \prime} W ; 160\right.$ m.a.s.l. WGS84), State of Maranhão, by G.V. Andrade and J.D. Lima on May 1998. This area is characterized by transitional forests between Amazon and Cerrado biomes (Veloso et al. 1991). This area is composed of both open savannas and forests, which are associated with rivers (Cerradão and Mata dos Cocais), which, by their turn, are influenced by the Tocantins and Araguaia rivers drainages systems.

We identified the referred specimen as Teratohyla midas based on known characters (Lynch and Duellman 1973, Guayasamin et al. 2009) and comparisons with photographs of the holotype (KU 123219).

This new record extends the known geographic range of Teratohyla midas approximately $1200 \mathrm{~km}$ southeast from the nearest reported area (Crique Grand Leblond, French Guyana [Kok and Castroviejo-Fisher 2008]) being the easternmost record for this glassfrog. Also, this record represents the first for glassfrogs in the transitional area between Amazon and Cerrado biome. Hence, $T$. midas geographic distribution is associated to Peruvian, Ecuadorian, Colombian and Brazilian Amazonian lowlands and a disjoint populations occurring in French Guyana, and northern Brazilian lowlands, at transitional forested remnants between Amazon and Cerrado in Tocantins River drainage systems (Figure 2).

Kok and Castroviejo-Fisher (2008) emphasized that the disjoint distribution of Teratohyla midas is an artifact due to the lack of sample effort across the Amazon Basin and Guyana Shield. An increase in sampling effort in these areas may reveal the presence of this species in other forested fragments, thus filling its distributional gap. Another hypothesis raised by those authors, is that T. midas corresponds to a species complex. However, only studies conducted in view of fresh collected specimens, bioacustical, and molecular data will reveal if unrecognized species are contained within $T$. midas. 


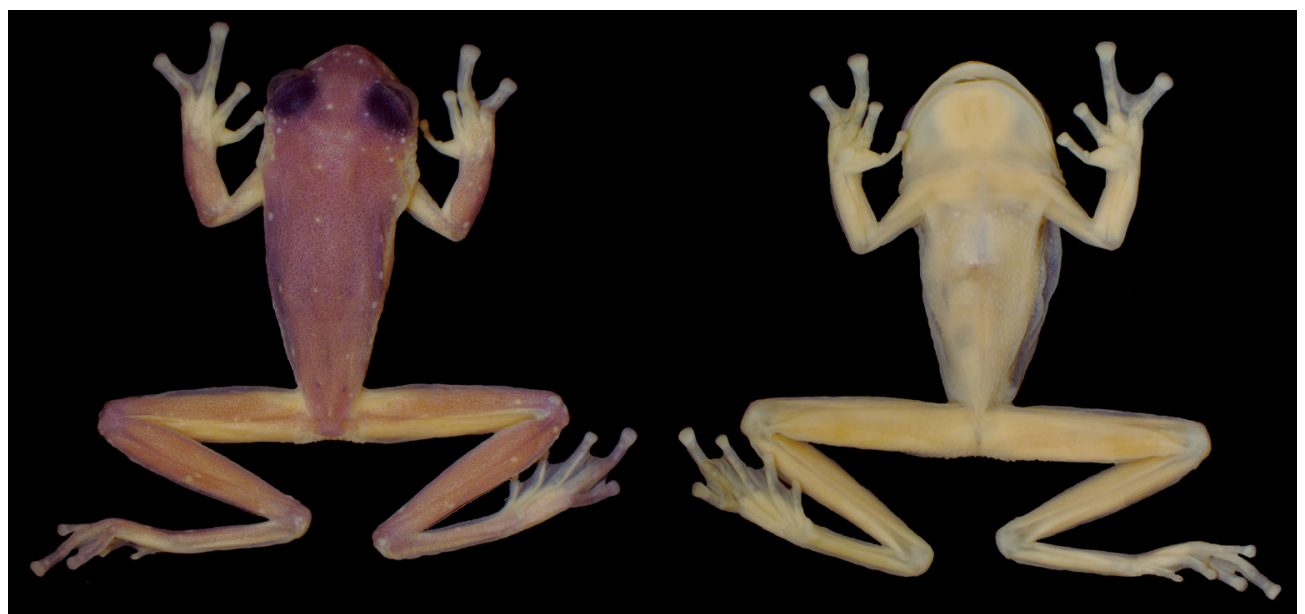

FigURE 1. Teratohyla midas (MNRJ 23856). SVL $19.5 \mathrm{~mm}$.

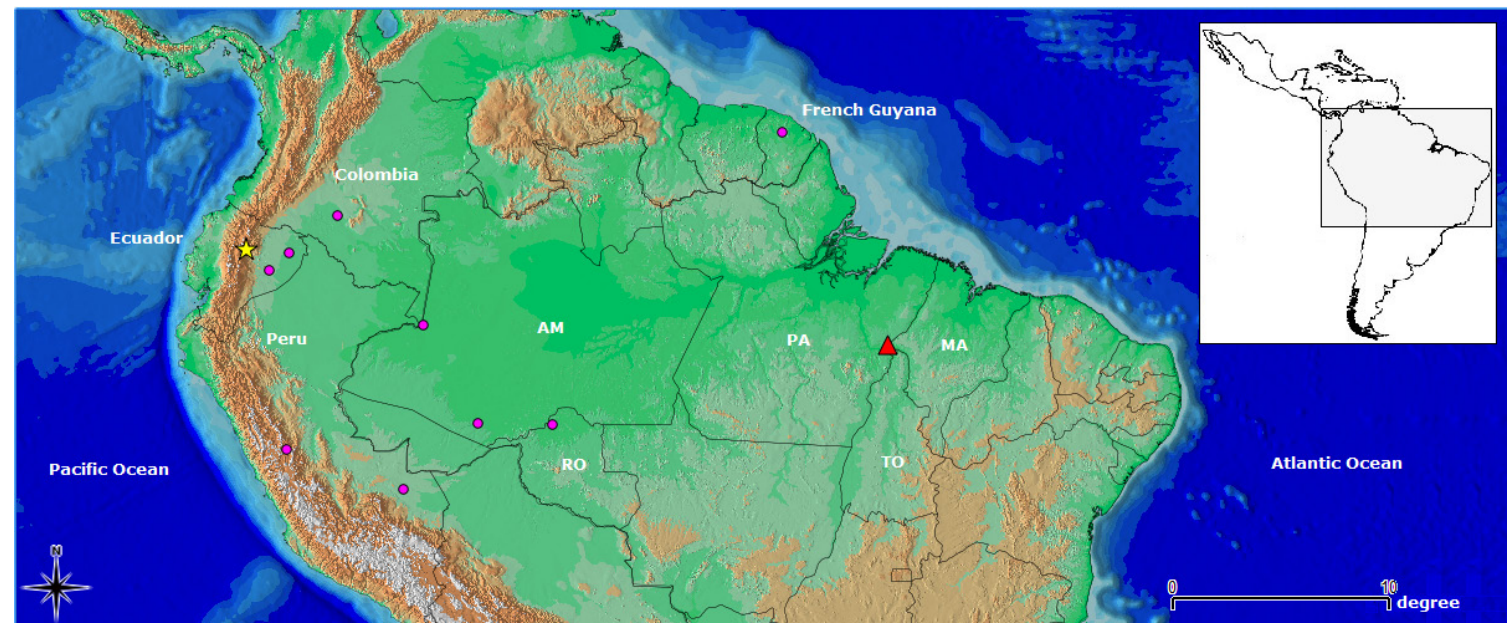

FiguRE 2. Distribution map of Teratohyla midas. Yellow star: type-locality (Santa Cecília, Província de Napo, Ecuador); Pink circle: literature records - Rodriguez et al. 2004 (Panguana, Departament of Huánuco and Pakitza Department of Madre de Dios, Peru) Cisneros-Heredia and McDiarmid 2005 (Province of Orellana, Napo, and Pastaza, Ecuador); Lynch 2005 (Letícia, Department of Amazonas, Colombia); Kok and Castroviejo-Fisher 2008 (Crique Grand Leblond, French Guyana); França and Venâncio 2010 (Boca do Acre, estado do Amazonas, Brazil); Melo-Sampaio and Oliveira 2013 (Porto Velho, Rondônia, Brazil); Malambo et al. 2013 (Belén de los Andaquies and Florencia Department of Caquetá, Colombia); red triangle: new record for São Pedro da Água Branca, Maranhão, Brazil.

ACKNowledgments: We are grateful to Juan M. Guayasamin for providing photos of the holotype of Teratohyla midas. RP and CM thank the Coordenação de Aperfeiçoamento de Pessoal de Nível Superior - CAPES for their scholarship grants. We also thanks to Conselho Nacional de Desenvolvimento Científico e Tecnológico - $\mathrm{CNPq}$ and Fundação de Amparo a Pesquisa do Estado do Rio de Janeiro - FAPERJ for the equipment support to Setor de Herpetologia, Museu Nacional / Universidade Federal do Rio de Janeiro.

\section{Literature Cited}

Castroviejo-Fisher, S., C. Vilà, J. Ayarzagüena, M. Blanc and R. Ernst. 2011. Species diversity of Hyalinobatrachium glassfrogs (Amphibia: Centrolenidae) from the Guyana Shield, with the description of two new species. Zootaxa 3132: 1-55

Cisneros-Heredia, D.F. and R.W. McDiarmid. 2005. Amphibia, Centrolenidae, Centrolene peristictum, Centrolene presoblepon, Cochranella cochranae, Cochranella midas, Cochranella resplendens, Cochranella spinosa, Hyalinobatrachium munozorum: range extensions and new provincial records. Check List 1(1): 18-22.

Cisneros-Heredia, D.F. and R.W. McDiarmid. 2007. Revision of the characters of Centrolenidae (Amphibia: Anura: Athesphatanura), with comments on its taxonomy and the description of new taxa of glassfrogs. Zootaxa 1572: 3-82.

França, F.G.R. and N.M. Venâncio. 2010. Reptiles and amphibians of a poorly known region in southwest Amazonia. Biotemas 23(3): 71-84.

Frost, D.R. 2013. Amphibian Species of the World: an Online Reference. Version 5.5 (9 January, 2013). Electronic Database accessible at http://research.amnh.org/vz/herpetology/amphibia/ American Museum of Natural History, New York, USA. Captured on 22 May 2013.

Guayasamin, J.M., S. Castroviejo-Fisher, L. Trueb, J. Ayarzaguena, M. Rada and C. Vila. 2009. Phylogenetic systematics of Glassfrogs (Amphibia: Centrolenidae) and their sister taxon Allophryne ruthveni. Zootaxa
2100: 1-97.

Heyer, W.R. 1985. Taxonomic and natural history notes on frogs of the genus Centrolenella (Amphibia: Centrolenidae) from southeastern Brasil and adjacent Argentina. Papeis Avulsos de Zoologia. 36, 1-21.

Kok, P.J.R. and S. Castroviejo-Fisher. 2008. Glassfrogs (Anura: Centrolenidae) of Kaieteur National Park, Guyana, with notes on the distribution and taxonomy of some species of the family in the Guyana Shield. Zootaxa 1680, 25-53.

Lynch, J.D. 2005. Discovery of the richest frog fauna in the World an exploration of the forests to the north of Leticia. Revista de la Academia Colombiana de Ciencias 29(113): 581-588.

Lynch, J.D. and W.E. Duellman. 1973. A review of the Centrolenid frogs of Ecuador, with descriptions of new species. Occasional Papers, Museum Natural History, University Kansas 16: 1-66.

Malambo, C., J.F. González-Ibarra and Y.C. Gomez-Polania. Amphibia, Anura, Centrolenidae Teratohyla midas (Lynch and Duellman, 1973) and Cochranella resplendens (Lynch and Duellman, 1973): First and second record respectively for Colombia. Check List 9(4):894-896

Melo-Sampaio, P.R. and Oliveira, C.M.B. 2013. Teratohyla midas Brazil: Rondônia: Porto Velho. Herpetological Review 44(1): 104.

Rodríguez, L. J.L. Martinez, C. Azevedo-Ramos, L.A. Coloma and S. Ron. 2004. Teratohyla midas In IUCN 2012. IUCN Red List of Threatened Species. Version 2012.1. Electronic database accessible at www. iucnredlist.org. Acessed on 05 September 2013.

Veloso, R.B., A.L.R. Rangel Filho and J.C.A. Lima. 1991. Classificação da vegetação brasileira, adaptada a um sistema universal. Rio de Janeiro: IBGE.

RECEIVED: December 2012

ACCEPTED: July 2013

Published ONLINE: December 2013

EDITORIAL RESPONSIBILITY: Marcelo Nogueira de Carvalho Kokubum 